\title{
EFFECT OF VARIETY, SOWING DATE AND LOCATION ON YIELD AND NUTRITIONAL CHARACTERISTICS OF SORGHUM
}

\author{
Ivana Koláčková1 ${ }^{1}$, Daria Baholet ${ }^{1}$, Hana Abigail Gruberová1,

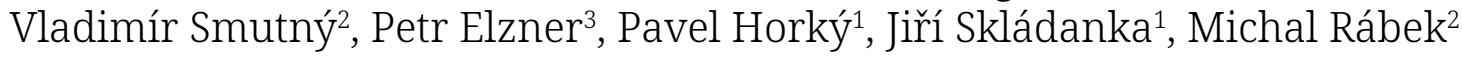 \\ ${ }^{1}$ Department of Animal Nutrition and Forage Production, Faculty of AgriSciences, Mendel University in Brno, \\ Zemědělská 1, 61300 Brno, Czech Republic \\ ${ }^{2}$ Department of Agrosystems and Bioclimatology, Faculty of AgriSciences, Mendel University in Brno, \\ Zemědělská 1, 61300 Brno, Czech Republic \\ ${ }^{3}$ Department of Crop Science, Breeding and Plant Medicine, Faculty of AgriSciences, Mendel University in Brno, \\ Zemědělská 1, 61300 Brno, Czech Republic
}

Link to this article: https://doi.org/10.11118/actaun202068030529

Received: 24. 3. 2020, Accepted: 14. 5. 2020

To cite this article: KOLÁČKOVÁ IVANA, BAHOLET DARIA, GRUBEROVÁ HANA ABIGAIL, SMUTNÝ VLADIMÍR, ELZNER PETR, HORKÝ PAVEL, SKLÁDANKA JIŘÍ, RÁBEK MICHAL. 2020. Effect of Variety, Sowing Date and Location on Yield and Nutritional Characteristics of Sorghum. Acta Universitatis Agriculturae et Silviculturae Mendelianae Brunensis, 68(3): 529-537.

\begin{abstract}
Sorghum is a forage species important in animal nutrition with an increased potential in the upcoming difficulties in agricultural practices in regard to climate change. Therefore, this paper describes its yield and nutritional parameters depending on growing conditions simulated on two locations (humid and fertile Obora, less fertile and dry Písky), two sowing dates (29. 5. and 25. 6.), and variety (11 varieties). Fresh matter yield was determined by weighing the sample on the field immediately after harvest, Dry matter yield and nutritional content were determined in laboratory by Weende analysis from dried and homogenized samples. Nutritional parameters measured were crude fibre, fat, nitrogen and ash content. Additionally, digestibility of organic as well as dry matter was determined.

No significant differences in average fresh matter yield or dry matter yield were found between the two locations and sowing dates in general. There were significant differences among varieties, the highest yields were measured in KWS Zerberus ( $51.57 \pm 3.76 \mathrm{t} / \mathrm{ha}$ of fresh matter yield, $15.98 \pm 1.34 \mathrm{t} / \mathrm{ha}$ of dry matter yield, with higher values observed on Písky). Our data suggest, that sowing date does significantly affect fat content (higher in June sowing). Other nutritional parameters were also higher in sorghum sown in June, with the exception of ash. Nutritional composition of samples did not significantly differ variety to variety, however, there were differences in digestibility of the biomass. Organic matter digestibility was 70.58-85.67\%, dry matter digestibility was 73.21-86.70\%, with highest digestibility in DMS 45-480. Varieties with the highest importance to farmers in the area are KWS Zerberus, KWS Tarzan and KWS Kallisto (based on dry matter yield), and Triumfo BMR, Sweet Susana and DSM 45-480 (based on digestibility). Sorghum was able to perform well even on dry sandy soil with lower fertilization, which shows the high variability and suitability of sorghum in agricultural practice.
\end{abstract}

Keywords: drought-resistance, feed quality, forage grass 


\section{INTRODUCTION}

Genus Sorghum contains plants with C4metabolism typical for tropical and subtropical areas, and belongs to family Poaceae, subfamily Panicoideae (Taylor, 2019). This climate-smart crop has been grown for more than 3000 years predominantly in Africa and Eurasia, but its use has also spread to America and Australia (Patil, 2017). With increasing temperature, more frequent and prolonged drought periods is yield of main cereals (such as wheat and maize) predicted to decline in main production areas by year 2100 due to climate change (Patil, 2017). This phenomenon enables other lesser grown crops to get to the forefront of farmers' interest and possibly even demand. Nowadays sorghum production in the world stagnates (Taylor, 2019). Total export of sorghum from Czech Republic has declined from $65 \mathrm{t}$ in 2013, to mere 14t in 2016 (FAO, 2020). However, sorghum's potential to face current agricultural issues caused by climate change is enormous.

Sorghum's high adaptability to soil and climate conditions can be possibly attributed to its genetic variability (Taylor, 2019). It is drought and salinity resistant undemanding crop with considerable ecological importance (Wang et al., 2018; Tari et al., 2012). These attributes make it suitable for multiple different uses, such as industrial processing (bioethanol fuel, thatching, starch and syrups production), food and feed production (Taylor, 2019).

Sorghum can be divided into four main types according to preferences in end use - sweet sorghum (high stem-sugar content, especially sucrose), forage sorghum (good palatability and forage quality), grain sorghum (good grain quality and size) and sorghum for biomass or bioenergy (Taylor, 2019). From an animal nutrition point of view, sweet, forage and grain sorghum types are the most relevant, however, it is important to acknowledge its genotype and phenotype variability (Kanbar et al., 2019). This paper is focusing on differences in dry matter and fresh matter yields of different varieties and also its suitability for growing in the climate of temperate areas with low rainfall.

Future of sorghum production is therefore contingent on the growers' ability to breed suitable varieties for this use. Grains of sorghum, wheat and maize are comparable in energy values, with high polysaccharide and protein content (Are et al., 2019; Cardoso et al., 2016; Queiroz et al., 2015). However, sorghum may contain several antinutritional compounds, such as kafirin or phytate P (Selle et al., 2018). Furthermore, bioactive compounds such as 3-deoxyanthocyanidins, tannins, and polycosanols occurring in most of the sorghum varieties can be beneficial for animal health in the long term (Cardoso et al., 2016).

Hence this paper brings relevant information on 11 sorghum varieties gathered from experimental work in two different locations (fertile and humid site - Obora, and dry site - Písky) to the forefront of general public's attention and shows possible applications of the data in sorghum growing, harvesting and nutritional values.

\section{MATERIALS AND METHODS}

\section{Characteristic of Experimental Location}

The field experiment was realised in Žabčicefield station $\left(49^{\circ} 00^{\prime} 50.3^{\prime \prime} \mathrm{N}, 16^{\circ} 36^{\prime} 03.6^{\prime \prime} \mathrm{E}\right)$, located in the maize production area of the South Moravia region, 179 a. s. l. This area is among the warmest regions in the Czech Republic with average annual precipitation of $480 \mathrm{~mm}$ distributed unevenly throughout the vegetation season. Arid conditions of this area are enhanced by wind-caused substantial evaporation of soil surface moisture. Sunshine duration is 1800-2000 hours per year. Average temperature is $9.2{ }^{\circ} \mathrm{C}$ with warmest average temperatures in July $\left(19.3^{\circ} \mathrm{C}\right)$ and lowest in January $\left(-2.0^{\circ} \mathrm{C}\right)$. Meteorological data was gathered by dataloggers placed in agroclimatologic station on the field station premises. The average monthly temperatures and precipitations from the sowing date to the harvest can be found in the Tab. I below.

I: Average monthly temperature and precipitation in Žabčice during the experiment

\begin{tabular}{lcc}
\hline & Temperature $\left({ }^{\circ} \mathrm{C}\right)$ & Precipitation $(\mathrm{mm})$ \\
\hline May & 12.6 & 79 \\
June & 22.8 & 67 \\
July & 21 & 55.4 \\
August & 21.7 & 72.4 \\
September & 15.6 & 46 \\
October & 10.6 & 10.6 \\
\hline
\end{tabular}

First site named Obora has clay loam soil and the soil type is fluvisol. Obora has good availability of groundwater (Svratka River), which fluctuates 0.8-2.5 $\mathrm{m}$ below the soil surface during the year. The second site named Písky has light sandy arenic cambisol with naturally lower fertility in comparison to Obora.

\section{Plant Material and Trial Establishment}

Sowing material was obtained from companies KWS and SEED SERVICE. Names and use of the tested varieties can be found in Tab. II. Varieties marked by "BMR" after the variety name describes those types of sorghum that have typical brown central (mid) rib on the leaves, reduced content of lignin (40-60\%), and higher digestibility (Hermuth et al., 2012).

Sowing rate was 245,000 seeds/ha, preceding crop was spring barley. In Obora, levels of pH/CaCl: 6.88 . The content of micronutrients according to Melich III 
II: Classification and utilization purpose of tested varieties

\begin{tabular}{llc} 
& Classification & Use \\
\hline Arsenio & S. bicolor $\times$ S. bicolor & grain \\
DSM 45-480 & S. bicolor $\times$ S. bicolor & grain \\
KWS Kallisto & S. bicolor $\times$ S. bicolor & silage \\
KWS Merlin & S. bicolor $\times$ S. bicolor & biomass \\
KWS Sole & S. bicolor $\times$ S. sudanense & silage, biomass \\
KWS Tarzan & S. bicolor $\times$ S. bicolor & silage, biomass \\
KWS Zerberus & S. bicolor & silage \\
PSE CE BMR & S. bicolor $\times$ S. bicolor & grain, silage, biomass \\
Ruzrok & S. bicolor & biomass, grain \\
Sweet Susana & S. bicolor $\times$ S. bicolor & biomass, silage, grain \\
Triumfo BMR & S. bicolor $\times$ S. sudanense & silage, grain \\
\hline
\end{tabular}

III: List of tested varieties, providing companies and harvest dates

\begin{tabular}{|c|c|c|c|c|c|}
\hline & \multirow[b]{3}{*}{ Company } & \multicolumn{4}{|c|}{ Harvest date } \\
\hline & & \multicolumn{2}{|c|}{ OBORA } & \multicolumn{2}{|c|}{ PÍSKY } \\
\hline & & $1^{\text {st }}$ sowing & $2^{\text {nd }}$ sowing & $1^{\text {st }}$ sowing & $2^{\text {nd }}$ sowing \\
\hline Arsenio & Seed Service & 14. 08. 2018 & 25. 09. 2018 & 14. 08. 2018 & 25. 09. 2018 \\
\hline DSM 45-480 & Seed Service & 22. 08. 2018 & 25. 09. 2018 & 22. 08. 2018 & 25. 09. 2018 \\
\hline KWS Kallisto & KWS & 14. 08. 2018 & 25. 09. 2018 & 14. 08. 2018 & 25. 09. 2018 \\
\hline KWS Merlin & KWS & 22. 08. 2018 & 03. 10. 2018 & 22. 08. 2018 & 03. 10. 2018 \\
\hline KWS Sole & KWS & 30. 08. 2018 & 25. 09. 2018 & 30. 08. 2018 & 25. 09. 2018 \\
\hline KWS Tarzan & KWS & 30. 08. 2018 & 03. 10. 2018 & 30. 08. 2018 & 03. 10. 2018 \\
\hline KWS Zerberus & KWS & 30. 08. 2018 & 03. 10. 2018 & 30. 08. 2018 & 03. 10. 2018 \\
\hline PSE CE BMR & Seed Service & 30. 08. 2018 & 03. 10. 2018 & 30. 08. 2018 & 03. 10. 2018 \\
\hline Ruzrok & Seed Service & 14. 08. 2018 & 25. 09. 2018 & 14. 08. 2018 & 25. 09. 2018 \\
\hline Sweet Susana & Seed Service & 22. 08. 2018 & 03. 10. 2018 & 22. 08. 2018 & 03. 10. 2018 \\
\hline Triumfo BMR & Seed Service & 22. 08.2018 & 03. 10. 2018 & 22. 08. 2018 & 03. 10. 2018 \\
\hline
\end{tabular}

were P: $84 \mathrm{mg} / \mathrm{kg}, \mathrm{K}: 175 \mathrm{mg} / \mathrm{kg}$, Ca: $4000 \mathrm{mg} / \mathrm{kg}$, Mg: 268 mg/kg. Content of Cox was 1.76\%. In Písky were levels of $\mathrm{pH} / \mathrm{CaCl}_{2} 6.6 \mathrm{mg} / \mathrm{kg}, \mathrm{P}: 110 \mathrm{mg} / \mathrm{kg}$, K: 235 mg/kg, Ca: 3211 mg/kg, Mg: 296 mg/kg, sand $61.8 \%$, silt $25.1 \%$, clay $13.1 \%$.

Two fertilization regimes were tested to enhance the difference between locations and simulate the performance of sorghum varieties in different conditions. Obora site was fertilised by $120 \mathrm{~kg} / \mathrm{ha}$ $\mathrm{K}_{2} \mathrm{O}, 90 \mathrm{~kg} / \mathrm{ha} \mathrm{P}_{2} \mathrm{O}_{5}$ (applied in October 2017) and $120 \mathrm{~kg} / \mathrm{ha} \mathrm{N}$ (applied in the form of urea on the date of sowing and incorporated into the upper layers of soil by ridge harrow). Písky site was only fertilised with nitrogen in the same amount as in Obora.

To assess the ability of sorghum varieties to grow during the drought season, two sowing dates were compared in terms of yield. Date of the first sowing was 29. 5. 2018 and the date of second sowing was 25. 6. 2018. Harvest dates can be found in Tab. III.

\section{Analyses of Sorghum Samples}

Samples were gathered depending on the dry matter content (above 23.94\%) after approximately 100 days (depending on the variety). Dry matter content of sorghum forage is used as a quality indicator in silage preparation and therefore was the determining factor for the harvest date in our experiment. Biomass was harvested by hand and weighted immediately. Yield of fresh matter (FMY) in was subsequently calculated.

At the same time, samples for analyses of dry matter yield (DMY) and nutritional content were gathered. All analyses of nutrients in feed were carried out in Brno, Czech Republic, according to the methodology for determination of the nutrient content (Horký, 2014). Above-ground biomass was shredded twice to ensure uniformity during the drying process. Part of the samples were dried at $103{ }^{\circ} \mathrm{C}$ for 24 hours for 
dry matter content analysis. For Weende analysis of nutritional value composition of feed were the samples dried at $60{ }^{\circ} \mathrm{C}$ for 24 hours. Afterwards were samples milled to $1 \mathrm{~mm}$ particle size that created homogenous powder and used in further analyses.

Ash was determined by burning the powdered sample at $600{ }^{\circ} \mathrm{C}$ and after oxidation of all organic matter was the resulting inorganic residue weighed and ash content calculated.

Content of nitrogenous substances was measured by Kjeldahl method. It is based on sample digestion in concentrated sulphuric acid with a catalyst resulting in conversion of $\mathrm{N}$ substances into ammonium sulphate in a solution that was neutralised by caustic soda lye. Ammonia was captured by boric acid in steam distillation and titrated. Total N substances content was calculated.

Fat and Crude Fibre (CF) was determined using Soxhlet method of solids' extraction. These nutrients were measured by extracting of fat or CF using a solvent covering the powdered sample in a porous thimble placed in the Soxhlet extractor with condenser. After total dissolving of fat or $\mathrm{CF}$ was the sample weighed and content of the nutrient was calculated.

Other parameters, such as Acid Detergent Fibre (ADF), Neutral Detergent Fibre (NDF) were analysed by ANKOM Fibre Analyser (ANKOM Technology, Macedon, USA). The sample was analysed by placing and weighing the plant material into filter bags and refluxing these samples in hot neutral or acid detergent solution. After 1 hour it was rinsed, dried and weighed again. Percentage of NDF or ADF in dry matter was calculated.

Dry Matter Digestibility (DMD) and Organic Matter Digestibility (OMD) were measured by in vitro enzymatic pepsin-cellulase assay in accordance to the ČSN 46 7092-3 (467092) norm specification. This means it was analysed by simulating ruminant digestion over a 4-day period using acidified pepsin, thermostable alpha amylase and cellulase. Disappearance of dry matter and organic matter was determined in the process.

\section{Statistical Evaluation}

All measurements were statistically evaluated and graphically depicted using Statistica, version 12.0 (TIBCO Software, Palo Alto, USA). Results are expressed as mean or mean \pm standard error. Normality of data was tested by Shapiro-Wilk test. Statistical significance of differences among observed factors was determined using ANOVA, Sheffé's test and T-test for normal data. Otherwise, nonparametric KruskalWallis ANOVA and median test were used. Differences with $\mathrm{P}<0.05$ were regarded as statistically significant.

\section{RESULTS}

Higher average yields of all grown varieties were measured in Obora (FMY $=36.84 \pm 2.24 \mathrm{t} / \mathrm{ha}$, $\mathrm{DMY}=11.56 \pm 0.65 \mathrm{t} / \mathrm{ha}$ ) in comparison to Písky
$(\mathrm{FMY}=33.62 \pm 2.71 \mathrm{t} / \mathrm{ha}, \mathrm{DMY}=11.14 \pm 0.72 \mathrm{t} / \mathrm{ha})$. However, there were no significant differences between yields in terms of location (Tab. IV). Significantly higher ash content was observed in Písky (6.99 $\pm 0.17 \%)$ in comparison to Obora $(6.44 \pm 0.12 \%)$.

Sowing date caused significant differences only in fat content, with higher percentage measured in second sowing in June $(2.16 \pm 0.08 \%)$ in comparison to first sowing in May (1.80 $\pm 0.08 \%)$. Besides ash content, level of each analysed nutrition was higher in the second sowing. Yield was not significantly different as well, with somewhat higher DMY in the June sowing and higher FMY in the first sowing.

In terms of variety, there were statistically significant differences observed in yields. Farmers often attach great importance to yields; however, it is crucial to compare also other performance parameters of sorghum. Lowest values of FMY were observed in varieties KWS Sole (23.12 $\pm 0.37 \mathrm{t} / \mathrm{ha})$, Ruzrok $(23.28 \pm 1.08 \mathrm{t} / \mathrm{ha})$ and DSM 45-480 (24.24 \pm 1.86 t/ha). Lowest values of DMY were observed in DSM 45-480 $(7.47 \pm 0.50 \mathrm{t} / \mathrm{ha})$, Arsenio (8.77 $\pm 1.2 \mathrm{t} / \mathrm{ha})$ and Sweet Susana (8.79 \pm 0.39 t/ha). Highest average FMY was measured in KWS Zerberus (51.57 $\pm 3.76 \mathrm{t} / \mathrm{ha})$, KWS Tarzan (51.35 \pm 2.69 t/ha) and KWS Merlin (46.73 \pm 1.94 t/ha). Highest average DMY was measured in KWS Zerberus (15.98 \pm 1.34 t/ha), KWS Tarzan (15.91 \pm 1.19 t/ha) and KWS Kallisto (14.21 $\pm 0.96 \mathrm{t} / \mathrm{ha})$.

Horizontal statistical evaluation showed that there was no significant effect of sowing date on FMY or DMY depending on variety. Location was affecting the FMY in case of KWS Zerberus and Triumfo BMR varieties. Higher KWS Zerberus' FMY was found on Písky, higher Triumfo BMR's FMY was found on Obora. This points to higher water and nutrient requirements in Triumfo BMR in comparison to KWS Zerberus Also DMY of KWS Zerberus was significantly higher on Písky location in comparison to Obora. DMY was significantly affected by location in case of Arsenio as well, with higher average on Obora.

Digestibility of dry matter and organic matter is an important parameter in animal nutrition. Statistically significant differences were found among tested varieties (Fig. 1). The lowest values were observed in KWS Kallisto (DMD $73.21 \pm 1.57 \%$, OMD $70.58 \pm 2.12 \%$ ), Ruzrok (DMD $73.99 \pm 3.11 \%$, OMD $71.46 \pm 3.71 \%$ ) and KWS Sole varieties (DMD $74.13 \pm 2.03 \%$, OMD $71.91 \pm 2.48 \%$ ). The highest digestibility was observed in Triumfo BMR (DMD $79.57 \pm 0.72 \%$, OMD $77.90 \pm 0.64 \%$ ), Sweet Susana (DMD $82.11 \pm 0.94 \%$, OMD $80.62 \pm 0.97 \%$ ) and DSM 45-480 (DMD $86.70 \pm 1.22 \%$, OMD $85.67 \pm 1.41$ ).

Overall, tested varieties have shown only small differences in nutritional composition (Fig. 2). Only statistically significant difference was proven in case of fibre content (CF as well as ADF and NDF). 
IV: Average values of fresh and dry matter yields according to variety, location and sowing date

\begin{tabular}{|c|c|c|c|c|c|c|c|c|}
\hline & \multicolumn{4}{|c|}{ OBORA } & \multicolumn{4}{|c|}{ PÍSKY } \\
\hline & \multicolumn{2}{|c|}{ Fresh Matter Yield (t/ha) } & \multicolumn{2}{|c|}{ Dry Matter Yield (t/ha) } & \multicolumn{2}{|c|}{ Fresh Matter Yield (t/ha) } & \multicolumn{2}{|c|}{ Dry Matter Yield (t/ha) } \\
\hline & $1^{\text {st }}$ Sowing & $2^{\text {nd }}$ Sowing & $1^{\text {st }}$ Sowing & $2^{\text {nd }}$ Sowing & $1^{\text {st }}$ Sowing & $2^{\text {nd }}$ Sowing & $1^{\text {st }}$ Sowing & $2^{\text {nd }}$ Sowing \\
\hline Arsenio & 36.71 & 40.71 & $10.25^{\mathrm{a}}$ & $11.37^{\mathrm{a}}$ & 29.56 & 26.67 & $7.08^{b}$ & $6.38^{\mathrm{b}}$ \\
\hline DSM 45-480 & 27.77 & 26.8 & 8.42 & 8.13 & 22.62 & 19.78 & 7.12 & 6.22 \\
\hline KWS Kallisto & 40.00 & 52.27 & 13.09 & 17.1 & 40.40 & 41.60 & 13.14 & 13.53 \\
\hline KWS Merlin & 44.31 & 42.76 & 12.45 & 12.01 & 51.24 & 48.62 & 13.96 & 13.25 \\
\hline KWS Sole & 23.33 & 22.04 & 11.21 & 10.59 & 23.38 & 23.73 & 11.37 & 11.54 \\
\hline KWS Tarzan & 57.96 & 52.76 & 18.69 & 17.01 & 45.2 & 49.51 & 13.34 & 14.61 \\
\hline KWS Zerberus & $44.27^{\mathrm{a}}$ & $46.7^{\mathrm{a}}$ & $13.4^{\mathrm{a}}$ & $13.94^{\mathrm{a}}$ & $58.67^{b}$ & $57.42^{b}$ & $18.49^{b}$ & $18.09^{b}$ \\
\hline PSE CE BMR & 29.07 & 33.42 & 10.83 & 12.46 & 25.42 & 25.56 & 10.75 & 10.8 \\
\hline Ruzrok & 25.28 & 20.27 & 9.63 & 7.72 & 23.24 & 24.36 & 9.26 & 9.71 \\
\hline Sweet Susana & 33.47 & 31.73 & 8.43 & 8.13 & 26.8 & 23.51 & 9.92 & 8.7 \\
\hline Triumfo BMR & $41.87^{\mathrm{a}}$ & $37.87^{\mathrm{a}}$ & 10.24 & 9.27 & $24.89^{b}$ & $27.47^{\mathrm{b}}$ & 8.48 & 9.36 \\
\hline $\begin{array}{l}\text { Average } \\
\text { per sowing }\end{array}$ & $36.73^{A}$ & $36.97^{\mathrm{A}}$ & $11.51^{\mathrm{B}}$ & $11.61^{\mathrm{B}}$ & $33.77^{\mathrm{A}}$ & $33.48^{\mathrm{A}}$ & $11.17^{\mathrm{B}}$ & $11.11^{\mathrm{B}}$ \\
\hline $\begin{array}{l}\text { Average } \\
\text { per location }\end{array}$ & \multicolumn{2}{|c|}{$36.85^{\mathrm{A}}$} & \multicolumn{2}{|c|}{$11.56^{\mathrm{B}}$} & \multicolumn{2}{|c|}{$33.62^{\mathrm{A}}$} & \multicolumn{2}{|c|}{$11.14^{\mathrm{B}}$} \\
\hline
\end{tabular}

Legend: Significant differences between effects of sowing date and location on average yields evaluated vertically are marked by capital letters (A, B), significant differences between yields depending on the location within each variety were evaluated horizontally and marked by lowercase letters $(a, b)$. Differences in varieties' fresh matter yields depending on location are coloured green, dry matter yields are coloured orange.

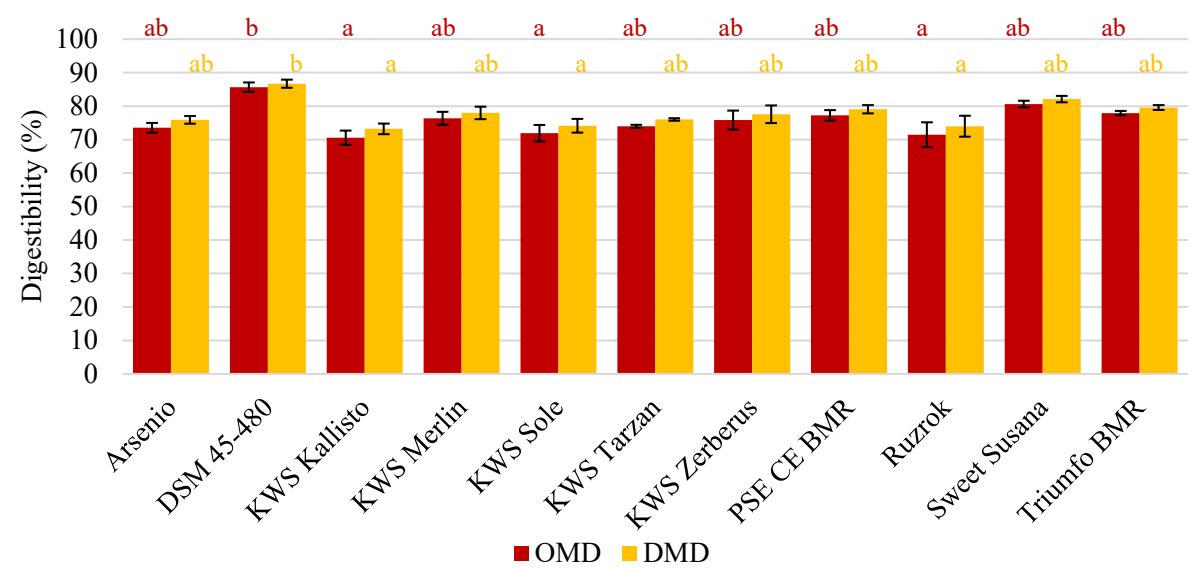

1: Average values of dry and organic matter digestibility according to variety

Legend: Red columns mark Organic Matter Digestibility (OMD) levels, yellow columns mark Dry Matter Digestibility (DMD) levels in sorghum samples. Columns with different letters (a, $\mathrm{b}, \mathrm{ab}$ ) indicate the statistically significant differences in mean values of case of individual groups within the sampling $(\mathrm{P}<0.05)$; Results are expressed as a mean \pm standard error (SE).

Lowest fibre content was observed in DSM 45-480 variety with $20.68 \pm 1.00$ of $\mathrm{CF}, 25.06 \pm 1.26 \% \mathrm{ADF}$ and $39.57 \pm 1.88 \%$ NDF (Fig. 3). Highest in fibre was KWS Kallisto with $30.84 \pm 1.21 \%$ of CF, $38.27 \pm 1.73 \%$ $\mathrm{ADF}$ and $58.50 \pm 0.77 \%$ NDF respectfully. Data gathered in other nutritional analyses is suggesting the highest fat, $\mathrm{N}$ and ash content in Arsenio and
DSM 45-480 varieties. Ash content in our experiment reached values from $6.00 \pm 0.23 \%$ (KWS Sole) to $7.25 \pm 0.64 \%$ (Arsenio), $\mathrm{N}$ content was from $8.26 \pm 0.27 \%$ (KWS Zerberus) to $10.16 \pm 0.59 \%$ (DSM 45-480) and fat content was from $1.65 \pm 0.13 \%$ (KWS Tarzan) to $2.38 \pm$ 0.19\% (DSM 45-480). 


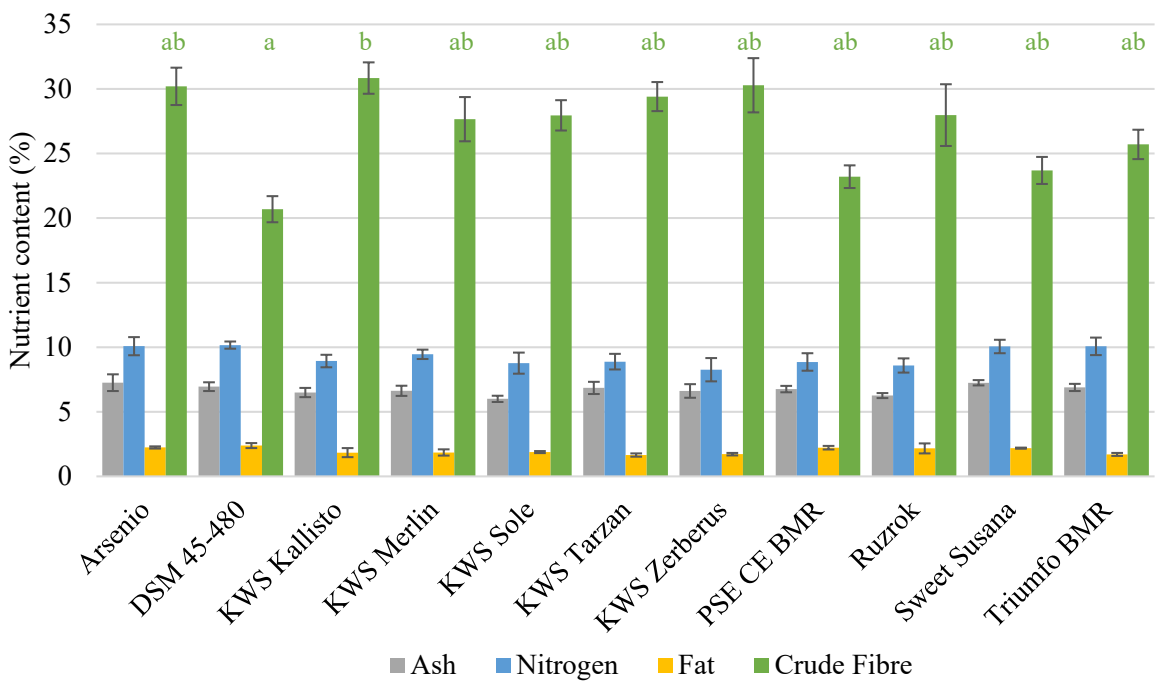

2: Average values of nutritional characteristics (CF, fat, $N$ and ash) of observed varieties expressed as proportion of total laboratory dry matter

Legend: Gray columns mark Ash levels, blue columns mark Nitrogen, yellow columns mark Fat levels and green columns mark Crude Fibre (CF) levels in sorghum samples. Columns with different letters ( $a, b, a b)$ indicate the statistically significant differences in mean values of case of individual groups within the sampling $(\mathrm{P}<0.05)$; Results are expressed as a mean \pm standard error (SE).

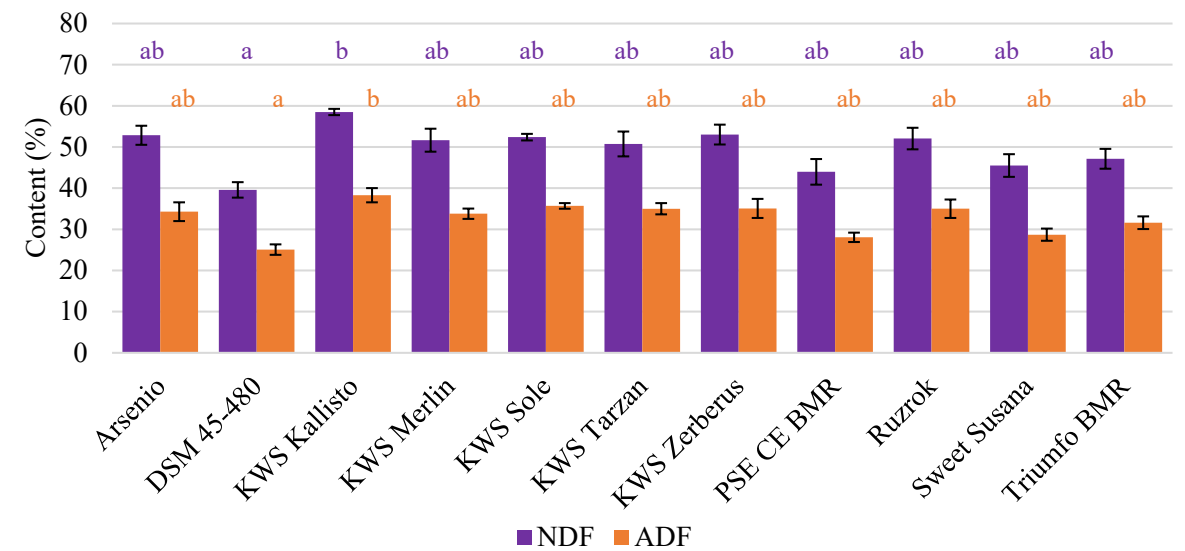

3: Average acid detergent fibre (ADF) and neutral detergent fibre (NDF) values of observed varieties expressed as proportion of total fibre

Legend: Purple columns mark Neutral Detergent Fibre (NDF) levels, orange columns mark Acid Detergent Fibre (ADF) levels in sorghum samples. Columns with different letters (a, b, $\mathrm{ab}$ ) indicate the statistically significant differences in mean values of case of individual groups within the sampling ( $\mathrm{P}<0.05)$; Results are expressed as a mean \pm standard error (SE).

\section{DISCUSSION}

Average yield of sorghum sown in our experiment was 33.62-36.84 t/ha of FMY and 11.14-11.56 t/ha of DMY. In the study of Hermuth et al. (2012), average DMY of tested sorghum varieties was $16.56 \mathrm{t} / \mathrm{ha}$, which is higher in comparison to our data. However, increase of DMY is achieved by wilting the harvested biomass for 24 hours on a field, as was the case in their experiment. The highest DMY values were measured in Troubsko (27.06 t/ha), where average temperatures during the year were the highest out of observed locations. Sweet Susana variety was found to have FMY of $64 \mathrm{t} / \mathrm{ha}$ and DMY of $14.9 \mathrm{t} / \mathrm{ha}$, however, in our study it was only 23.51-33.47 t/ha of FMY and 8.13-9.92 t/ha of DMY, depending on the location (Povolny and Hampl, 2015). This can be caused by extreme weather conditions (prolonged drought period) in the year 2018. Extremely high temperatures were measured in the months June and August. June measured month average $22.8^{\circ} \mathrm{C}$ normal average $17.7^{\circ} \mathrm{C}$, August measured month average $21.7^{\circ} \mathrm{C}$, normal average $18.6^{\circ} \mathrm{C}$. These findings can suggest the high potential for future agricultural use of sorghum in higher and lower production systems in climate change-affected areas. 
According to Nakmee et al. (2016), arbuscular mycorrhiza may affect sorghum yield. Highest efficiency in mycorrhizal improvement of nutritional uptake and consequently increase in biomass and dry weight of sorghum was revealed in case of Acaulospora scrobiculata.

According to Hermuth et al. (2012), it is possible to grow sorghum without the need of irrigation in areas with yearly annual precipitation levels of 400$700 \mathrm{~mm}$ with low soil requirements in comparison to maize. Furthermore, costs of growing sorghum are estimated to be 20,000-30,000 CZK/ha, which is similar to maize $(18,000 \mathrm{CZK} / \mathrm{ha}$ for silage maize and 33,500 CZK/ha for grain maize) (Hermuth et al., 2012; Treuová, 2017). Economics of farming would not be affected, however less input may be possible in terms of irrigation and fertilisation. Our data shows that there is no difference in sorghum's performance between locations (more fertile Obora or less fertile and drier Písky) in most of the tested varieties. This is not the case for varieties KWS Zerberus (higher FMY and DMY on Písky), Triumfo BMR (higher FMY on Obora) and Arsenio (higher DMY in Písky). Tolerance to dry and less fertile soil without significant differences in yield was supported by our study as well as other authors and therefore is the key characteristic of this crop (Taylor, 2019; Wang et al., 2018). This supports the hypothesis of sorghum's suitability for South Moravian forage production.

Crop response to water deficiency and nitrogen vary with the local conditions, thus it is quite significant to test sorghum response to different irrigation regimes and nitrogen treatments under local conditions. It was declared in previous studies that irrigation levels influenced lignin and water-soluble sugar content, thus altered in vitro digestibility of sorghum silage (Carmi et al., 2006; Yosef et al., 2009). Therefore, water and nitrogenous fertilizers should be so properly applied that they should improve efficient use of plant nutrients, produce high yields (Kim et al., 2008) and preserve silage quality as well as feed digestibility.

In vivo sheep digestibility of short and tall sorghum varieties was evaluated by Yosef et al. (2009). No significant differences were found in NDF and cellulose content between two variants irrespective of the growth season, however digestibility and $\mathrm{CP}$ intake was higher in short sorghum genotype.

According to a study of Hermuth et al. (2012), sorghum has higher ash (6-12\%), crude fibre (32-44\%) and NDF (48-62\%) content, and higher DMY, in comparison to maize. Similar sugar, fat and lignin contents were found in both crops observed in their experiment. In our study, ash and fat content was similar (6-7.25\% and 1.65-2.38\% respectfully), however total fibre and NDF values were lower (20.68-30.84\% and 39.57-58.5\% respectfully).

Sorghum bran is high in fibre and therefore can be utilized separately as a feed component (Bean et al., 2019). Sorghum-based pellets were found to enhance feed intake and overall performance of broilers in comparison to sorghum in the form of mash or re-grinded pellets (Abdollahi et al., 2014).

Although high nutritional value of sorghum grains and forage is documented, a number of antinutritional compounds may be also present. Sorghum contains high amounts of kafirin that may lower digestibility and efficiency of energy utilization of grains. This is an important factor in poultry and pig nutrition (Selle et al., 2018). Kafirins, the principal seed storage proteins in sorghum, accounting for $70-80 \%$ of total protein, are a major contributing factor to the poor digestibility of sorghum grain (Wong et al., 2010). Post-harvest processing is an essential factor in nutritional value of sorghum. Kafirin content differs depending on the plant and grain part and thereby it is possible to separate kafirin-rich part of endosperm from the rest of the grain to reduce its overall concentration in feed.

In the study of Yang et al. (2019) effect of sorghum-based diet on production performance of dairy cows was observed. Sorghum silage fed cows showed similar nutrient digestibility to corn-silage fed animals and in conclusion can be used as a corn replacement in their diet while sustaining the levels of production performance. This is in accordance with observations made by Ronda et al. (2019), that sorghum has $95 \%$ or higher feeding value (depending on its quality) in comparison to yellow dent maize.

No differences in yields were found in the May and June sowing dates in any of the observed varieties and locations. Generally, higher FMY and DMY were measured in second (June) sowing on Obora, and first (May) sowing on Písky, however, these differences were not statistically significant. USA experiment on relationship between harvest date and DMY has shown almost linear increase, with as much as 15.8 t/ha of DMY/ha in the soft dough stage. However, differences in nutritional profile were observed. DM, starch and non-fibre carbohydrates' content increased, but crude protein and NDF levels decreased (Lyons et al., 2019).

\section{CONCLUSION}

Sorghum is a secondary forage grass species, nowadays mostly used merely as an addition to traditional cereals in livestock nutrition. However, by monitoring 11 varieties, this paper suggests its great potential in animal feed production. It can demonstrably withstand drought and low fertility soil conditions of South Moravia, while maintaining high average yields, which was demonstrated by 
no statistical significance of location on yield in most varieties. Therefore, lower water and nitrogen supply is acceptable for sorghum without any significant losses in yield and quality parameters, with the exception of Triumfo BMR's FMY and Arsenio's DMY. Average yields of fresh matter were 33.62-36.84 t/ha, and yields of dry matter were 11.14-11.56 t/ha. Two sowing dates are possible to implement in observed area (late May and late June), with no significant differences in performance of chosen varieties. This makes sorghum very plastic crop suitable for wide spectrum of locations and management regimes. Sorghum had lower ash content and higher fibre, fat and nitrogen content, although yields stayed similar. The most suitable varieties for silage production (according to its DMY) are KWS Zerberus (grown on less humid and fertile soil), KWS Tarzan and KWS Kallisto. The highest digestibility was observed in Triumfo BMR, Sweet Susana and DSM 45-480.

Acknowledgements

The research was financially supported by the AF-IGA-2018-tym001: Comparison of the impact of climate change on photosynthesis C3 and C4 plants cycles which are used in livestock feed.

\section{REFERENCES}

ABDOLLAHI, M. R., RAVINDRAN, V. and SVIHUS, B. 2014. Influence of feed form on growth performance, ileal nutrient digestibility, and energy utilisation in broiler starters fed a sorghumbased diet. Livestock Science, 165: 80-86.

ARE, A. K. et al. 2019. Chapter 3 - Application of Plant Breeding and Genomics for Improved Sorghum and Pearl Millet Grain Nutritional Quality. In: TAYLOR, J. R. N. and DUODU, K. G. (Eds.). Sorghum and Millets (Second Edition). AACC International Press, pp. 51-68.

BEAN, S. R. et al. 2019. Chapter 6 - Starch and Protein Chemistry and Functional Properties. In: TAYLOR, J. R. N. and DUODU, K. G. (Eds.). Sorghum and Millets (Second Edition). AACC International Press, pp. 131-170.

DE MORAIS CARDOSO, L. et al. 2017. Sorghum (Sorghum bicolor L.): Nutrients, bioactive compounds, and potential impact on human health. Critical Reviews in Food Science and Nutrition, 57(2): 372390.

CARMI, A. et al. 2006. Effects of irrigation and plant density on yield, composition and in vitro digestibility of a new forage sorghum variety, Tal, at two maturity stages. Animal Feed Science and Technology, 131(1): 121-133.

FAOSTAT. 2020. Food and Agriculture Organisation of the United Nations. [Online]. Available at: http:// www.fao.org/faostat/en/\#home [Accessed: 2020, March 16].

CZECH NORMALIZATION INSTITUTE. 1998. Testing methods for feeding stuffs - Part 3: Determination of moisture content. ČSN 46 7092-3 (467092). Prague: ČSN.

HERMUTH, J. 2012. Sorghum - Sorghum bicolor (L.) MOENCH: options for use in Czech Republic: methodology for practice [in Czech: Čirok obecný - Sorghum bicolor (L.) MOENCH: možnosti využití $\checkmark$ podmínkách České republiky: metodika pro praxi]. Praha: Výzkumný ústav rostlinné výroby. Available at: https://www.vurv.cz/sites/File/Publications/ISBN978-80-7427-093-2.pdf [Accessed: 2020, March 16].

HORKÝ, P. 2014. Effect of Protein Concentrate Supplement on the Qualitative and Quantitative Parameters of Milk from Dairy Cows in Organic Farming. Annals of Animal Science, 14(2): 341-352.

KANBAR, A. et al. 2019. Morphological and molecular characterization of sweet, grain and forage sorghum (Sorghum bicolor L.) genotypes grown under temperate climatic conditions. Plant Biosystems, 154(1): 1126-3504.

KAPLAN, M. et al. 2019. Water deficit and nitrogen affects yield and feed value of sorghum sudangrass silage. Agricultural Water Management, 218: 30-36.

KIM, K.-I. et al. 2008. Do Synergistic Relationships between Nitrogen and Water Influence the Ability of Corn to Use Nitrogen Derived from Fertilizer and Soil? Agronomy Journal, 100(3): 551-556.

LYONS, S. E. et al. 2019. Optimal harvest timing for brown midrib forage sorghum yield, nutritive value, and ration performance. Journal of Dairy Science, 102(8): 7134-7149.

NAKMEE, P. S., TECHAPINYAWAT, S. and NGAMPRASIT, S. 2016. Comparative potentials of native arbuscular mycorrhizal fungi to improve nutrient uptake and biomass of Sorghum bicolor Linn. Agriculture and Natural Resources, 50(3): 173-178.

PATIL, J. V. 2016. Millets and Sorghum: Biology and Genetic Improvement. John Wiley \& Sons.

POVOLNY, M. and HAMPL, B. 2015. Results of field trials from harvest 2014 Sorghum [in Czech: Výsledky zkoušek užitné hodnoty ze sklizně 2014 čirok]. Available at: http://eagri.cz/public/web/file/291588/ Cirok_2013.pdf [Accessed: 2020, March 16]. 
QUEIROZ, V. A. V. et al. 2015. Nutritional composition of sorghum [Sorghum bicolor (L.) Moench] genotypes cultivated without and with water stress. Journal of Cereal Science, 65: 103-111.

RONDA, V. et al. 2019. Chapter 14 - Sorghum for Animal Feed. In ARUNA, C. et al. (Eds.). Breeding Sorghum for Diverse End Uses. Woodhead Publishing Series in Food Science, Technology and Nutrition. Woodhead Publishing, pp. 229-238.

SELLE, P. H. et al. 2018. Outlook: Sorghum as a feed grain for Australian chicken-meat production. Animal Nutrition, 4(1): 17-30.

TARI, I. et al. 2013. Response of Sorghum to Abiotic Stresses: A Review. Journal of Agronomy and Crop Science, 199(4): 264-274.

TAYLOR, J. R. N. 2019. Chapter 1 - Sorghum and Millets: Taxonomy, History, Distribution, and Production. In: TAYLOR, J. R. N. and DUODU, K. G. (Eds.). Sorghum and Millets (Second Edition). AACC International Press, pp. 1-21.

TREUOVA, A. 2017. Cultivation of Zea mays and its use in current economic conditions in Czech republic [in Czech: Pěstování a využití kukuřice seté v ekonomických podmínkách České republiky]. Bachelor Thesis. Brno: Mendelova Univerzita v Brně.

WANG, J. et al. 2018. Effect of Climate Change on the Yield of Cereal Crops: A Review. Climate, 6(2): 41. WONG, J. H. et al. 2010. Principal component analysis and biochemical characterization of protein and starch reveal primary targets for improving sorghum grain. Plant Science, 179(6): 598-611.

YANG, Y. et al. 2019. Production performance, nutrient digestibility, and milk fatty acid profile of lactating dairy cows fed corn silage- or sorghum silage-based diets with and without xylanase supplementation. Journal of Dairy Science, 102(3): 2266-2274.

YOSEF, E. et al. 2009. Characteristics of tall versus short-type varieties of forage sorghum grown under two irrigation levels, for summer and subsequent fall harvests, and digestibility by sheep of their silages. Animal Feed Science and Technology, 152(1): 1-11.

Contact information

Ivana Koláčková: ivana.kolackova@mendelu.cz

Daria Baholet: dariabaholet@gmail.com

Hana Abigail Gruberová: xgrubero@mendelu.cz

Vladimír Smutný: vladimir.smutny@mendelu.cz

Petr Elzner: petr.elzner@mendelu.cz

Pavel Horký: pavel.horky@mendelu.cz

Jiří Skládanka: jiri.skladanka@mendelu.cz

Michal Rábek: michal.rabek@mendelu.cz 